Калифорния) в 1931 году по поводу опухоли в левой половине мошонки, замсиенную им 6 недель пазад. 7 лет назад перешес гоноройный уретрит и простатит. Элидидимита ме было. При обследовании больного не удавалось отграничить слева в мошонке яичка от опухоли, которая исходила из иридатка. При пункции опухоли удалось получить 5 куб см прозратной жицкости, Јаховые желсзы слева и слрава пе увеличены. Семенные пузырьки не прощугывались. Перед онерацией был поставлен дигноз опухоли щридатка пибо туберкуњезиой этиологищ тибо злокачественого харзктера. Отеративным путем удалелы гридаток и опухоль, при гистологическом исследовании оказавшаяся карциномой.

$A \not$.

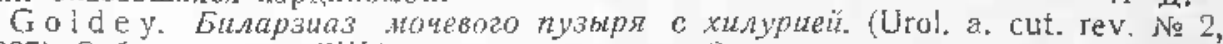
1937). Заболевание в США довольно редкое. Описывается спучай, касанцийся женцииы, котору автор паблюдаз с 1933 r. по поводу небольшой гематурин. В 1934 г. удалось установить правильную диагюстику заболевания благодаря mахокдению своеобразных опухолей в мочевом пузыре и яиц паразита в моче. Ленсние виннокаменнокислым аммонем путсм введени его расторов интавенозио. Уданось остановить гематурию, а также исчезла и хилурия, вызвнная проникновснисм ларазита в грудной лимфатический дроток. Лечение данпоо заболсвания паллиатиное н, несомнено, пеполноцениое

A. II.

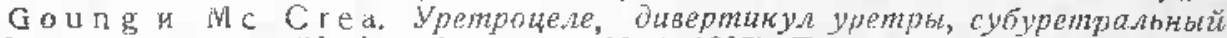
абсиесс у жсенцин. (Urol. and cut. rev. № 2, 1937). Под терминамй, укјзанными в загјавин статьи, аєторы понимат наличие мешка в нижней стенке уретры у женцин, располагаююегося между стенками уретры и вагины. Этот мецик ббычло наполне॥ тио́о мочей, либо глоем и соединяется каналом с нижней стенкой уретры. Урстроцеле легко диагносиировать путем уретрографии, ибо картин па рентенограмме харнктерна. Лечение, реконендусое авторами: введение в мешок склерозирующих растворов с целью вызвать слигчивое воспаление.

$\mathrm{V}$ in $\mathrm{i} \mathrm{ci}, \mathrm{V}$. и A I teres $\mathrm{cu}, \mathrm{H}$. (Бухарест) Скдерозируюиее лечение водинки яаtкa. (Journal d'Urol., Xa 4, т. XLII, 1936). На зассдании румынского урологичсского обшества қаворами сдслано сообщение о лечении воляики яичка препа-

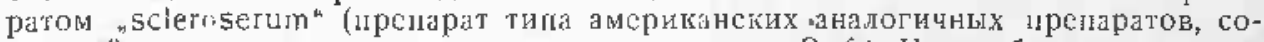
ставной цасіью которых является хиния и уретан. Реф.). ИІод наблюдсиисм авторов было 8 больных, из конх 3 были полностью излечены; из трех случаев .вторинной водянки на поцве хронических гоноройных эпидидимитов в двух случая получено излечение и 1 случай осталя без эффекта; в І случае с налияисм разращений в оболопках эффекта пе полутено и, наконец, в I слутае

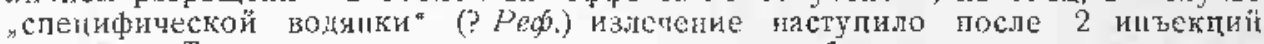
препарата. Техџика лсчения состоит в пункци оболочек, выкачивапии церез Iпприц жидкост и введения в полость от 1 до 5 см $^{2}$ раствора.

\title{
д) Cubusuc.
}

Le vy-Deke r, M. Po.s cugbuaca в заболеваниях носоглотки. (Ann. mal. ven., № 11. 1936). По статистике Ж а ке, относяцейся к 1912 г., 70\%о больных с полинами в носоглотке оказались больными сифилисон. насть синуситов возникает на почве сифилиса. В возникновении озены сифилис может такжс играть некоторую роль.

A. $\Omega$.

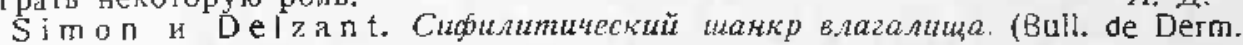
et de Syph, № 1, 1937.) Шапкры влагалипа являются исклюуительной редкостью. $\$$ ур п ье на 249 случаев шашкров у жснциин ни разу не наблюдал локализацию шанкра на стенке вагины.

Олисание случая касается жешцины, 25 лет, у которой шанк располагался иа стенке вагииы в виде эрозии, слегка кровоточащей с инфильтрированным осюовапием. Адснопатия паховая довольно значительно выражена При вункции желез обнаружелы спирохеты. Серореакции положительные. Специфическое лечение быстро лривено К эпитьлизации шанкра.

A. $I$.

$\mathrm{K}$ a ub i s chek. Буляезный caльварсанный дерлатum. (Arch $\mathrm{f}$. Derm, $\mathrm{u}$. Syph. Bd. 175, № 1, 1937) Болыой в латентной стадии сифилиса поссупил в ІЈражскую немецкую кожиую клинику с явлениями гоноройного артрита. ІІомимо лечения гоноройной инфекци больному начат курс специфического антисифиіт ическото лечегия. Послс 6-го вливания сальварсана (марка прегарата не указана. Реф.) на 4 й день после вливания у больного появились на 